\title{
膀胼平滑筋細胞内収縮機構の研究
}

一skinned fiber 法による検討一

\author{
福島県立医科大学泌尿器科学教室（主任：白岩康夫教授） \\ 金 谷 昇二 郎
}

\section{STUDY OF THE INTRACELLULAR CONTRACTILE MECHANISM OF THE URINARY BLADDER SMOOTH MUSCLE USING SKINNED FIBER THECHNIQUE}

\author{
Shojiro Kanaya \\ Department of Urology, Fukushima Medical College
}

(Director: Prof. Y. Shiraiwa)

The intracellular contractile mechanism of the urinary bladder smooth muscle was studied using the saponin-treated skinned fiber in which cell membrane was chemically removed.

The chemically skinned bladder muscle showed a tension development which was dependent on $\mathrm{Ca}^{2+}$-concentration. The minimal $\mathrm{Ca}^{2+}$-concentration for the tension development was $2 \times 10^{-7} \mathrm{M} \mathrm{Ca}^{2+}$. The maximal tension was induced at $10^{-5} \mathrm{M}$. This maximal tension was approximately the same as the $\mathrm{K}^{+}$-induced tension development observed in the intact muscle. In addition, SDS-polyacrylamide gel electrophoresis showed that the contractile proteins were still preserved in the saponin-treated bladder smooth muscle. The $\mathrm{Ca}^{2+}$-concentration-tension response curve shifted to the left with an increase in MgATP concentration (from $3 \mathrm{mM}$ to $7 \mathrm{mM}$ ), indicating that the sensitivity of the skinned muscle was affected by MgATP.

$\mathrm{Mg}^{2+}$ above $6 \mathrm{mM}$ caused a slow tension development by itself in the absence of $\mathrm{Ca}^{2+}$.

$\mathrm{Ca}^{2+}$-induced tension development was blocked by the addition of W-7 (calmodulin antagonist).

This result suggested that calmodulin ( $\mathrm{Ca}^{2+}$-binding protein) regulates the actin-myosin interaction in the urinary bladder smooth muscle.

Caffeine solution $(25 \mathrm{mM})$ caused a rapid tension development in the skinned bladder smooth muscle which was loaded with $\mathrm{Ca}^{2+}$-concentration, however, this tension development decreased when the loaded $\mathrm{Ca}^{2+}$-concentration exceeded $10^{-6} \mathrm{M}$.

It seems from this result that "Ca-induced-Ca release mechanism" also exists in the urinary bladder smooth muscle.

Key words: intracelluar contractile mechanism, skinned fiber, $\mathrm{Ca}^{2+}$.

要旨：膀胼平滑筋における細胞内収縮機構の解明を目的に, 家鬼膀脱の細胞膜のみを化学的に破壊し た筋線維“skinned fiber”を作製し，種々の検討を加えた。また少数例ではあるが，ヒト膀胱についても 同様の実験を行なった。膀胱 skinned fiber は一定濃度の $\mathrm{Mg}^{2+}, \mathrm{MgATP}$ の存在下に, $\mathrm{Ca}^{2+}$ 濃度に依存 性の収縮を示した。この時の $\mathrm{Ca}^{2+}$ 濃度は細胞外液中に比較し, きわめて低濃度であり, 収縮閾值は $2 \times$ $10^{-7} \mathrm{M}$ であった。 また最大張力は $10^{-5} \mathrm{M}$ で観察された。この最大張力は, 生筋の状態に拈ける $\mathrm{K}^{+}$収縮と ほぼ同程度であり, SDS-ゲル法における収縮蛋白の分析では, 生筋と skinned fiber との間に差は認めら れなかった. skinned fiberの $\mathrm{Ca}^{2+}$-sensitivity は収縮液中の MgATP 濃度によって变化した。一方, $\mathrm{Ca}^{2+}$ free の条件下であっても， $\mathrm{Mg}^{2+}$ 濃度の増加は skinned fiber の静止張力を増大させた. calmodulin は細 胞内 $\mathrm{Ca}^{2+}$ 結合蛋白として, 各種の細胞機能発現に深く関与していると考えられているが, calmodulin 阻 害剂 W-7はskined fiber の収縮を濃度依存性に抑制した。

一定時間 $\mathrm{Ca}^{2+}$ 溶液に浸漬した膀胼 skinned fiber は, $\mathrm{Ca}^{2+}$ free の caffeine 溶液の投与によって, 一過 
性の収縮反応を呈した。これは膀胱平滑筋 skinned fiberに招いてもCa-store が存在することを示す。 また $10^{-6} \mathrm{M}$ 以上の $\mathrm{Ca}^{2+}$ 濃度では，この収縮反応はむしろ減少したことょり，“Ca-induced Ca release mechanism”が示唆された。

キーワード：細胞内収縮機構, スキンドファイバー, カルシウムイオン

\section{緒言}

膀脱平滑筋の收縮機構に関する研究は, 種々の排尿 障害時に抢ける膀胖の様々な病態を理解する上で基礎 となり，また治療薬の選択や開発の指針ともなり，今 後ますます重要になるものと思われる．現在では自律 神経作動薬に対する反応 ${ }^{11}$ に加兄, 閉塞膀胱や除神経 膀胱における muscarinic receptor の定量や性質まで が検討されており ${ }^{223)}$, 膀胼平滑筋の細胞膜レベルにお ける収縮機構は次第に明らかとなりつつある。

一方, 膀脂平滑筋の収縮を細胞内レベルで捉えると, 結局は収縮蛋白であるアクチンとミオシンの相互反応 の結果生じたものであると言える。すなわちカルシウ ムイオン (以下 $\mathrm{Ca}^{2+}$ 略) の存在下でアクチンとミオ シンフィラメントが ATP を消費しながら打互に滑走 することである ${ }^{4) 5}$. このような細胞内収縮機構は，他 の平滑筋や骨格筋など筋組織一般に共通する収縮の基 本的プロセスと考兄られている6).ところが膀胱平滑 筋については, 先述した細胞膜レベルでの機序は比較 的よく研究されてきたのに対し，この細胞内収縮機構 についてはほとんど知られていないのが現状である。 一般に筋細胞内における収縮機構を検討する場合, 細 胞膜の持つ特異的機能は研究上大きな障害となるた め, 細胞膜のみが取り除かれ, 細胞内収縮システムが ほぼ完全な形で維持されている“skinned fiber”が必要 となる，そこで著者らは大梘らの考案したサポニン処 理法7を用いることにより，膀胱 skinned fiberを作製 し，その細胞内システムを詳細に検討したので報告す る.

\section{実験材料及び方法}

ネンブタール麻酔下に体重約 $3 \mathrm{~kg}$ の雄日本白色家鬼 から膀胱を摘出し, 実体顕微鏡下で筋の走行に沿って 約 $0.2 \times 3 \mathrm{~mm}$ の筋束標本を切離した。筇束は両端を 6 - 0 絹糸にて結び一方を organbath 内のフックに, 他 端を isometric transducer (日本光電社) に固定，95\% $\mathrm{O}_{2}+5 \% \mathrm{CO}_{2}$ の混合ガスを通気した $20^{\circ} \mathrm{C}$ の Lock 液 (155.2mM NaCl, $5.3 \mathrm{mM} \mathrm{KCl}, 3.6 \mathrm{mM} \mathrm{NaHCO}_{3}$, $1.8 \mathrm{mM} \mathrm{CaCl}_{2}, 2.8 \mathrm{mM}$ glucose) 中に垂直懸垂した. この organbath の容量は約 $3 \mathrm{ml}$ で溶液の排出, 注入を
図 1 膀胱 skinned fiber の発生張力測定法

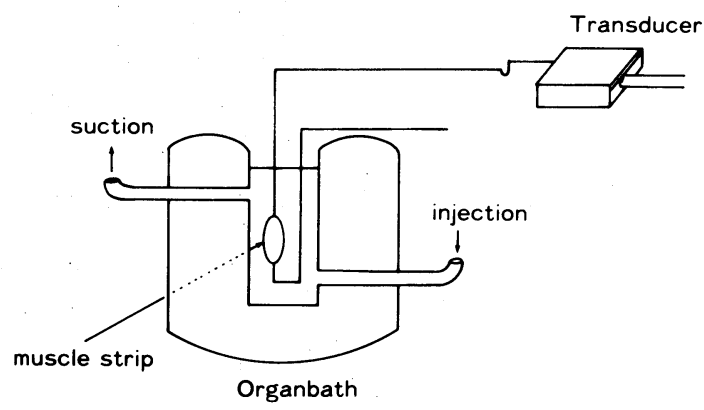

速やかに行なえる側孔を取り付けてある（図 1).

初めに organbath 内溶液を $2 / 3 \mathrm{~K}$ Lock 液 (Lock 液 中の $\mathrm{Na}$ の $2 / 3$ K で置換した溶液) に交換し, 生筋の 状態に打ける $\mathrm{K}^{+}$收縮を記録した。次に, Lock 液で筋 束を再び洗浄した後, skinned fiberの作製にとりか かった. 膀脂 skinned fiberは, この筋束を $100 \mu \mathrm{g} / \mathrm{ml}$ のサポニンを加えた4mM-EGTA 弛緩液 (130 mMKCl, $20 \mathrm{mM}$ Tris-maleate, $5 \mathrm{mM} \mathrm{MgCl}, 3 \mathrm{mM}$ ATP, $4 \mathrm{mM} \mathrm{EGTA,} \mathrm{pH} \mathrm{6.8,} \mathrm{20ㄷ)} \mathrm{中で} 30$ 分間処理 して作製した。 ヒト膀脱に関しては恥骨上前立腺摘出 術, あるいは膀脱全摘時の膀胼筋層部分より筋束標本 を切離し, 同様の方法でサポニン処理を行なった。膀 胱平滑筋 skinned fiber は，そのまま oganbath 内で張 カトランスデューサーに固定されているので, 種々の 条件下で起こる収縮蛋白の生化学的相互反応を張力の 発生として観察することができる。

実験は筋収縮システムの $\mathrm{Ca}^{2+}$ に対する感受性の検 討から始めた。 この際, 種々の濃度の $\mathrm{Ca}^{2+}$ 含む収縮 液は, $2 \mathrm{mM}$ EGTA 弛緩液(弛緩液中の EGTA $2 \mathrm{mM}$ にしたもの, 他は $4 \mathrm{mM}$ EGTA弛緩液と同組成）に Imai らの方法に準じて $\mathrm{CaCl}_{2}$ を加えて調整した ${ }^{8)}$.

また, MgATP が skinned fiber の $\mathrm{Ca}^{2+}$ 依存性收縮 へ与える影響を調べると共に, マグネシウムイオン(以 下 $\mathrm{Mg}^{2+}$ と略)単独の効果についても検討を加えた。さ らに, 細胞内の $\mathrm{Ca}^{2+}$ 受容蛋白である calmodulin の関 与について, calmodulin 阻害哓である W-7を用いて解 析した. 
細胞内 Ca-store の性質を検討する実験では $\mathrm{Ca}^{2+} の$ 主な貯蔵部位と考学られている筋小胞体が，サポニン やEGTA に対して不安定であることが知られている ため7)，サポニン処理の際の弛緩液は2mM EGTA 使用し，またサポニンの濃度は $40 \sim 60 \mu \mathrm{g} / \mathrm{ml}$ とし， 20〜30分間の処理によって skinned fiberを作製した。 また, $\mathrm{Ca}^{2+}$ 溶液の調整は0.1mM EGTA 弛緩液を使用 し, skinned fiber の洗浄も0.1mM EGTA 溶液を使用 した。この条件下で, Ca-store から $\mathrm{Ca}^{2+を}$ 放出させる 作用がある caffeine（25mM）を skinned fiber に投与 し，収縮反応を分析した。最後に実験に使用した skin-

図 2 SDS ゲル泳動法による収縮蛋白の分析．A：生 筋, B：サポニン処理後の skinned fiber サポニン処 理された skinned fiberでもアクチン・ミオシンのバ ンドが生筋と同様に分離されている。

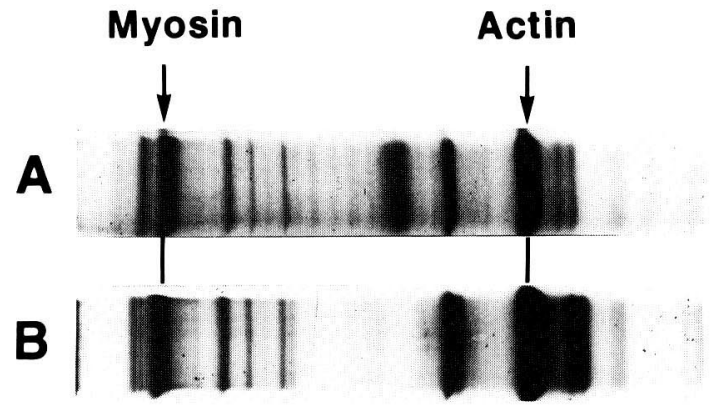

ned fiber 5 個についてそれぞれホモジナイズし, SDS ゲル電気泳動法により収縮蛋白の泳動分離を行ない, 生筋と比較した。

\section{結＼cjkstart果}

1) 生筋々 skinned fiber $の$ 比較

SDS-polyacrylamide gel electrophoresisによっ て, skinned fiber の収縮蛋白の組成を生筋と比較した (図 2 ). その結果，サポニン処理が加兄られていても アクチン抢よびミオシンは分解されず生筋と同じ泳動 パターンを示し， skinned fiber の収縮蛋白はよく保存 されていることが明らかとなった。

膀胱平滑筋 skinned fiber では，bath 内の弛緩液を $\mathrm{Ca}^{2+}$ を含んだ収縮液に置換すると著明な張力発生が 観察された（図 3 ）。この発生張力は一度上昇したのち

図 3 生筋と skinned fiber の収縮の比較 左は生筋の $2 / 3 \mathrm{~K}$ Lock 液による $\mathrm{K}^{+}$収縮，右は同一 標本のサポニン処理後の $10^{-5} \mathrm{M} \mathrm{Ca}^{2+} に よ る$ 收縮, $\mathrm{W}$ は洗浄を表わす。
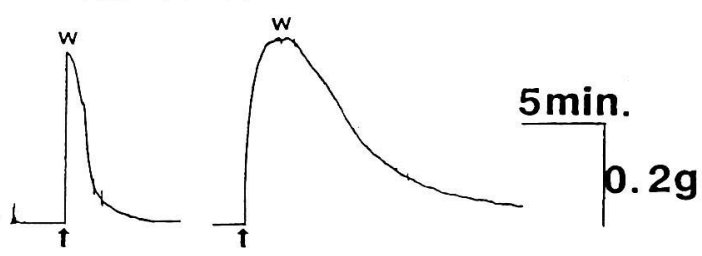

high $\mathrm{K} \quad 10^{-5} \mathrm{Ca}$

図 4 各濃度の $\mathrm{Ca}^{2+}$ 溶液に対する膀胼 skinned fiber の収縮

A：家鬼膀胼 skinned fiber, B：ヒト膀胱 skinned fiber, W：洗浄

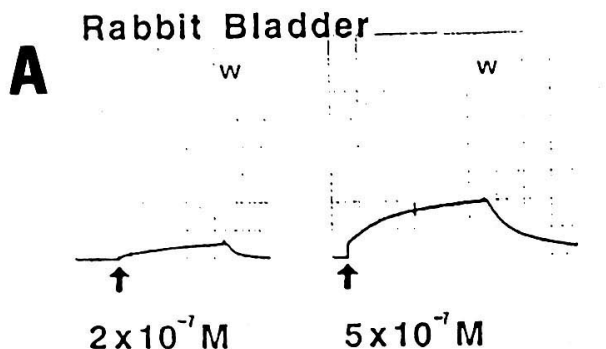

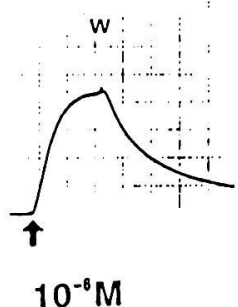

$10^{-8} \mathrm{M}$

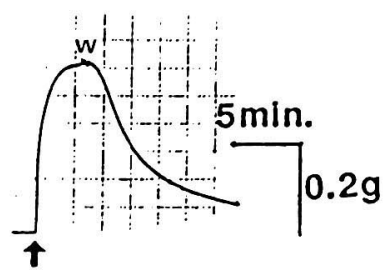

$10^{-5} \mathrm{M}$
B

\section{Human Bladder}

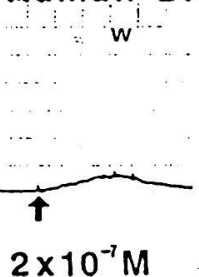

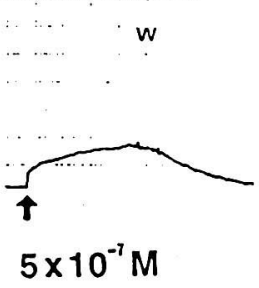

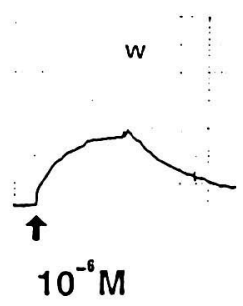

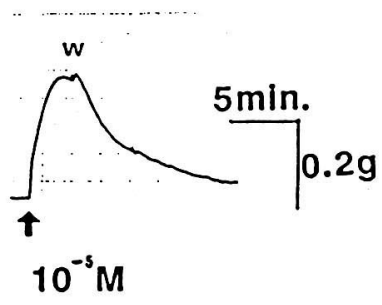


プラトーになり, $\mathrm{Ca}^{2+}$ が存在する限りその張力は比較 的よく維持された。次に bath 内を弛緩液で洗浄し $\mathrm{Ca}^{2+}$ 溶液を排除すると, 張力は徐々に低下し，もとの 静止レベルまで戻った。膀胱 skinned fiber の発生張力 を生筋のそれと比較すると, $10^{-5} \mathrm{M}$ の $\mathrm{Ca}^{2+}$ で発生する 張力の大きさは生筋における $\mathrm{K}^{+}$収縮とほぼ同程度で あったが，収縮および弛緩速度は生筋よりも遅かった (図 3 ).

2) skinned fiber の $\mathrm{Ca}^{2+}$ 感受性と MgATP の効果

膀胱 skinned fiber の発生張力と $\mathrm{Ca}^{2+}$ 濃度との関係 を, $\mathrm{Mg}^{2+を} 2 \mathrm{mM}, \mathrm{MgATP} 3 \mathrm{mM}$ と一定にした条件 下で検討した。ウサギ膀胱の skinned fiber では， $2 \times$ $10^{-7} \mathrm{M}$ の $\mathrm{Ca}^{2+}$ 濃度から張力発生がみられ, 発生張力の 大きさ及び収縮速度は $\mathrm{Ca}^{2+}$ 濃度が増すごとに増加し， $10^{-5} \mathrm{M}$ の濃度で最大収縮が得られた（図 $4 \mathrm{~A}$ )。また， ヒト膀胱の skinned fiberでも同様の所見が得られた (図 4B).

以上より膀胱 skinned fiber の $\mathrm{Ca}^{2+}$ 濃度一張力関係 は, $10^{-7} \mathrm{M}$ から $10^{-5} \mathrm{M}$ に至る比較的広い範囲で変動す る $\mathrm{S}$ 字状曲線となった（図 5 ).

次に, MgATP の張力発生に対する影響を観察する ために，収縮液中の $\mathrm{Mg}^{2+}$ 濃度を $2 \mathrm{mM}$ に固定したまま MgATP の濃度を標準の $3 \mathrm{mM}$ から $7 \mathrm{mM}$ に増加させ,
図 5 skinned fiber の発生張力と $\mathrm{Ca}^{2+}$ 濃度の関係 縦軸(tension) は $10^{-5} \mathrm{M}$ による最大収縮張力を $100 \%$ とした各濃度における張力を表わす。

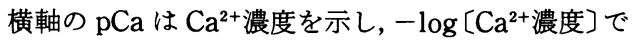
表わした。

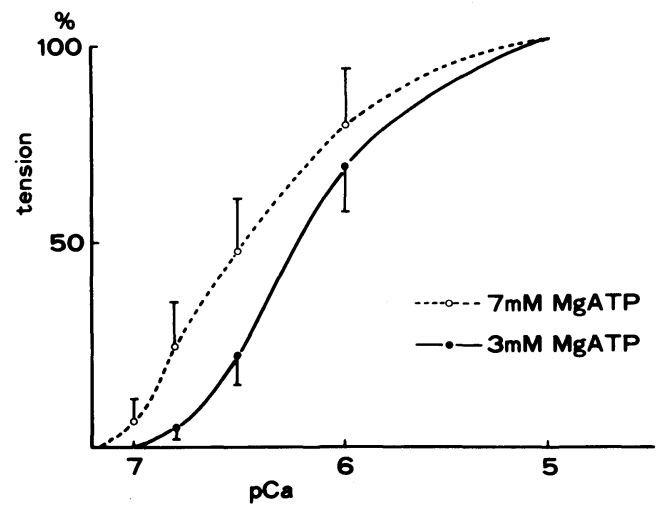

同様の実験を行なった。 その結果 MgATP の濃度が増 加した状態では, 同一の $\mathrm{Ca}^{2+}$ 一張力曲線は左方に偏位 した(図 5 )。すなわち, MgATPは膀胱 skinned fiber の $\mathrm{Ca}^{2+}$ に対する感受性を増大させることが明らかと なった.

3） $\mathrm{Mg}^{2+}$ 依存性収縮

困 $6 \mathrm{Mg}^{2+}$ による収縮 $\left(\mathrm{Ca}^{2+}\right.$ free 条件下) と $\mathrm{Ca}^{2+}$ による収縮の比較 $(\mathrm{MgATP}$ 濃度 はすべて3mM に固定）

$\mathrm{A}$ : 家鬼膀胱 skinned fiber, $2 \mathrm{mM} \mathrm{Mg}^{2+}$ 弛緩液で張力安定後, $\mathrm{Mg}^{2+}$ 濃度のみを6 $\mathrm{mM}, 8 \mathrm{mM}$ と増加させると, 濃度依存性にゆるやかな張力の発生を記録できる.こ れらの張力は $\mathrm{Ca}^{2+}\left(10^{-5} \mathrm{M}\right)$ による收縮と比較するときわめて小さい。

B：ヒト膀胱 skinned fiber について同様の実験結果を示す

A

A Rabbit Bladder
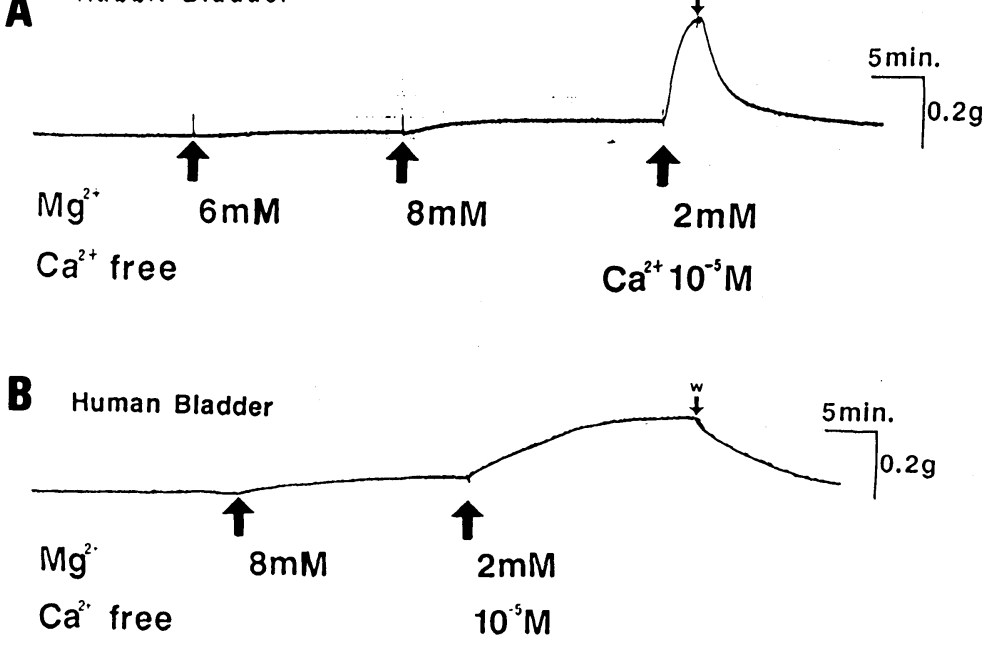
因 7 W-7による skinned fiber の収縮抑制効果

$\mathrm{A}$ ：家鬼膀腅， $10^{-6} \mathrm{M} \mathrm{Ca}^{2+}$ で収縮させた張力が平衡に達した後，W-7 $(100 \mu \mathrm{M})$ を 投与すると, $\mathrm{Ca}^{2+}$ 存在下でも skinned fiber は弛緩する。W-7の濃度を $300 \mu \mathrm{M}$ まで 増加させると弛緩速度はさらに増す。

$\mathrm{B}$ ：ヒト膀胱, W-7 $300 \mu \mathrm{M}$ の収縮抑制効果を示す。

$$
100 \mu \mathrm{M} \mathrm{W}-7 \quad 300 \mu \mathrm{M} \mathrm{W}-7
$$

A

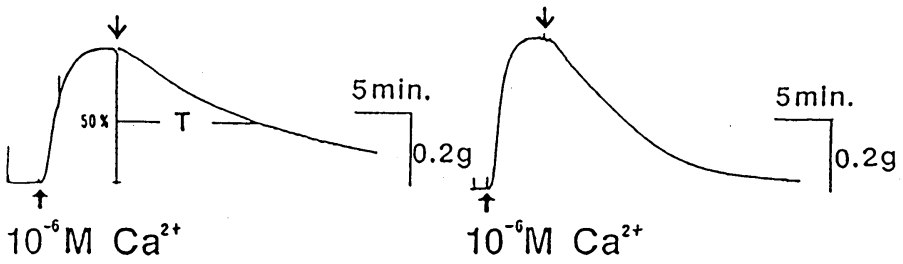

(Rabblt Bladder)

\section{$300 \mu \mathrm{M} W-7$}

B

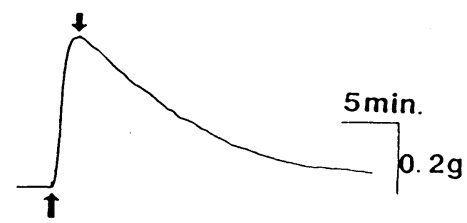

$10^{-6} \mathrm{M} \mathrm{Ca}$

(Human Bladder)

以上の $\mathrm{Ca}^{2+}$ に対する収縮の他に, $\mathrm{Mg}^{2+}$ 依存性収縮 が膀胱 skinned fiberにも存在するかについて検討し た. skinned fiber の静止張力が安定したところで, 弛 緩液中の MgATPを標準の3mMに固定したまま $\mathrm{Mg}^{2+}$ の濃度を増加させて張力変化を記録した. ウサギ 膀胱 skinned fiber は, $\mathrm{Mg}^{2+}$ 濃度が $6 \mathrm{mM}$ 以上になると 緩徐な張力発生を示した(図6A).この張力の大きさは $\mathrm{Ca}^{2+}$ による発生張力と比較するときわめて小さいる のであったが, skinned fiber は $\mathrm{Ca}^{2+}$ が存在しなくとも $\mathrm{Mg}^{2+}$ 単独で収縮することができた。 ヒト膀脱 skinned fiberでも同様の $\mathrm{Mg}^{2+}$ 依存性収縮が観察された（図 6 B).

4) calmodulin 阻害剂（W-7）の効果

細胞内収縮機構における calmodulin の関与をその 阻害剂であるW-7を用いて検討した。膀脱 skinned fiber $10^{-6} \mathrm{M}$ 濃度の $\mathrm{Ca}^{2+}$ で収縮させ，張力が平衡に なったところで, W-7を含んだ同一濃度の $\mathrm{Ca}^{2+}$ 溶液で bath 内を置換すると，著明な驰緩反応が認められた (図 7A).そこでW-7の他緩効果を, 最初の収縮張力の 半分まで弛緩するのに要する時間，すなわち張力の下 降速度で評価した. W-7の濃度が $100 \mu \mathrm{M}$ のとき，この Half Time (=T) は平均 $18.2 \pm 1.25 \mathrm{~min} て ゙, 300 \mu \mathrm{M}$
表 1 W-7 投与時の skinned fiber の収縮張力半減 時間の比較

\begin{tabular}{c|c}
\hline W-7 Concentration & $\begin{array}{c}\text { Half Times of Relaxation } \\
(\mathrm{T})\end{array}$ \\
\hline $100 \mu \mathrm{M}$ & $18.2 \pm 1.25 \min (\mathrm{n}=5)$ \\
\hline $300 \mu \mathrm{M}$ & $7.4 \pm 0.58 \min (\mathrm{n}=5)$ \\
\hline
\end{tabular}

にすると平均 $7.4 \pm 0.58 \mathrm{~min}$ とさらに短縮し,両者の間 に有意の差が証明された（表 1)。このように，W-7は skinned fiber の $\mathrm{Ca}^{2+}$ 収縮に対し，濃度依存性に弛緩速 度を増加させた。またヒ卜膀胀では, $300 \mu \mathrm{M} \mathrm{W}-7$ の効 果を検討したところ, 同一の弛緩現象が記録された(図 7B).

5）膀脱 skinned fiber における Ca-store の評価

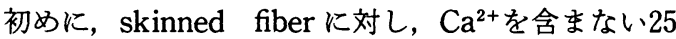
$\mathrm{mM}$ caffeine 溶液 (25mM caffeine, 0.1mM EGTA, $130 \mathrm{mM} \mathrm{KCl}, 20 \mathrm{mM}$ Tris-maleate, $5 \mathrm{mM} \mathrm{MgCl}_{2}, 3$ mM ATP）を投与し，Ca-store から $\mathrm{Ca}^{2+}$ を放出させ た. 次いで skinned fiberを $\mathrm{Ca}^{2+}$ 溶液に 5 分間浸漬し， Ca-store 内に $\mathrm{Ca}^{2+}$ 貯留させた。このように $\mathrm{Ca}^{2+を}$ 負荷した skinned fiber に対し, $25 \mathrm{mM}$ caffeine 溶液を 
図 8 Caffeine による skinned fiber の収縮 saponin 処理後, いったん caffeine 投与にて Castore 内の $\mathrm{Ca}^{2+を}$ 放出させる. 次に Ca-store 内に各 濃度の $\mathrm{Ca}^{2+}$ 負荷後 caffeineによる収縮を順次記 録した. caffeine による収縮はstore 一負荷される $\mathrm{Ca}^{2+}$ 濃度が $10^{-6} \mathrm{M}$ までは増加するが, $10^{-5} \mathrm{M}$ 負荷後 はむしろ減少した。

Caf : 25mM caffeine, W : 洗浄
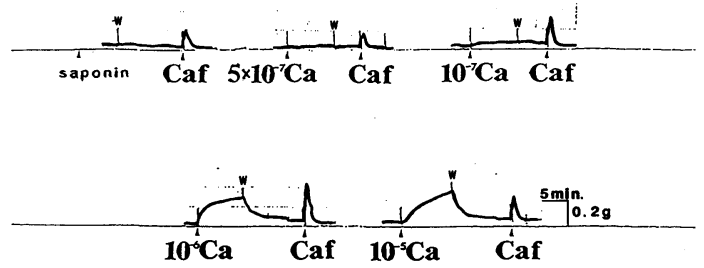

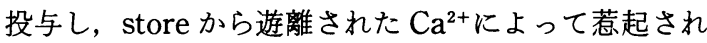
る収縮張力を記録した(図 8 ). caffeineによる収縮は, $\mathrm{Ca}^{2+}$ を負荷したときの収縮よりきわめて速く，負荷し た $\mathrm{Ca}^{2+}$ 濃度が $2 \times 10^{-7} \mathrm{M}, 5 \times 10^{-7} \mathrm{M}, 10^{-6} \mathrm{M}$ と増加す るに従って大きくなった。しかし， $10^{-5} \mathrm{M}$ 負荷後の収 縮張力は, $10^{-6}$ 負荷後の収縮張力ょりも小さかった(図 8 ).

平滑筋はその性質上，機械的な処理による skinned fiberの作製が困難である. そこで一時期グリセリン処 理法が用いられたが ${ }^{10)}$, 生筋に比較し, 細胞内収縮シス テムの維持には問題があった。これに対し, 斉田, 野々 村らはサポニン処理法が平滑筋の skinned fiber 作製 にきわめて有用であることを報告している11)，本実験 でも生筋と skinned fiberの比較を行なってみたが, SDS ゲル法による収縮蛋白のパターンは，両者の間に

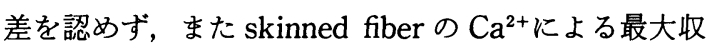
縮張力は，生筋の状態に拈ける $\mathrm{K}^{+}$収縮の大きさとほ ぼ同程度であった。これらの結果は，サポニン処理が 加えられても収縮に関与する細胞内のシステムはよく 保持されていることを示している。したがってサポニ ン処理による膀脱平滑筋 skinned fiber は本研究の目 的にあった優れた標本であると思われる。ただし， skinned fiber の收縮掞よび弛緩速度は, 生筋よりもや や劣っていた。この傾向は使用した筋束が太いほど明 瞭で skinned fiber では $\mathrm{Ca}^{2+}$ な゙゙の各種イオンの拡散 が生筋よりも時間を要するためと考えられた。

膀胱 skinned fiber は, $\mathrm{Ca}^{2+}$ に対して著明な張力発生 反応を示すのが特徵であった。他のイオン条件を $2 \mathrm{mM}$ $\mathrm{Mg}^{2+}, 3 \mathrm{mM} \mathrm{MgATP}$ と固定した状態で, 膀胱 skinned fiber の張力発生は $2 \times 10^{-7} \mathrm{M}$ の $\mathrm{Ca}^{2+}$ 濃度からみられ, $\mathrm{Ca}^{2+}$ 濃度が増すごとに発生張力も大きくなり, $10^{-5} \mathrm{M}$ で最大収縮を示した。 この $\mathrm{Ca}^{2+}$ 濃度と発生張力との関 係から, 膀羘平滑筋の細胞内収縮システムも, 他の平 滑筋と同様に $\mathrm{Ca}^{2+}$ にって制御されていると言らこ とができる，すなわち，筋収縮の基本であるアクチン フィラメントとミオシンフィラメントの滑走は, 膀胱 平滑筋においても細胞内 $\mathrm{Ca}^{2+}$ 濃度に依存していると 考えられる。このアクチンとミオシンの生化学的相互 反応には, 生体エネルギー物質である ATPを必要と する，ATPは脱リン酸化されて筋収縮エネルギーを 提供するが，実際の収縮においては $\mathrm{Mg}^{2+}$ 結合した MgATP の形でミオシンの基質として働く6). そこで この MgATP が skinned fiber の張力発生に与える影 響を検討したところ，MgATP の量が多いほど一定濃

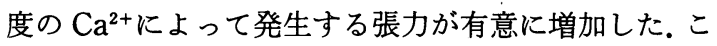
のよらな MgATPによる skinned fiberの $\mathrm{Ca}^{2+}$ 一感 受性の増大は, 腸管平滑筋などに括いても報告されて おり ${ }^{11)}$, 膀脱平滑筇においても MgATP は細胞内収縮 システムにおいて重要な役割をもつものと考えられ

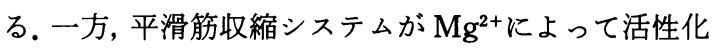
されることは, ミオシン B の超沈澱などで指摘されて きた ${ }^{12)}$ 。この現象を平滑筋 skinned fiberでみると, $\mathrm{Mg}^{2+}$ による張力発生として観察できることが知られ ている ${ }^{11}$. 著者の検討でも, 膀胱平滑筋 skinned fiber は, $\mathrm{Mg}^{2+}$ 濃度を $2 \mathrm{mM}$ から $6 \mathrm{mM}$ まで増加させると, $\mathrm{Ca}^{2+}$ が存在しないにもかかわらず, 緩徐な張力発生を 記録することができた. この $\mathrm{Mg}^{2+}$ による張力発生は, 現時点に打いてまだ解明されていない現象の一つであ る. 最近の研究では, 平滑筋細胞内でミオシンはかな り不安定な状態にあり, ミオシンが筋収縮装置として フィラメント構造をとるためには $\mathrm{Mg}^{2+}$ が必要である と言われている(13). しかしこの問題については, ミオシ ンフィラメント形成に関する電顕的研究も含めて, 今 後一層の検討が必要と思われた。

平滑筋の細胞内収縮システムが骨格筋と最も異なる 点は, $\mathrm{Ca}^{2+}$ 受容蛋白である calmodulin の関与である とされている ${ }^{14)}$. すなわち, 細胞内で一定濃度以上と なった $\mathrm{Ca}^{2+}$ は, 直接アクチンやミオシンなどの収縮蛋 白に作用するのではなく, 細胞内に存在する calmodulin に結合する。この $\mathrm{Ca}^{2+}$ と calmodulin の結合 体が，ミオシン軽鎖キナーゼを活性化し，ミオシンが リン酸化され，アクチンと相互反応することによって 筋収縮が起こる ${ }^{14) 15}$. しかし, これらの收縮制御機構は 
主に血管平滑筇，あるいはニワトリの砂囊などを用い て検討されたものであり, 膀脱平滑筋ではまだ実証さ れていない. 本研究究では calmodulin 阻害剂の中で も特に選択性の高い $\mathrm{W}-7^{16)}$ を用いて，膀胱平滑筋収縮 における calmodulin の関与を検討した。 その結果, 膀 脱 skinned fiber の $\mathrm{Ca}^{2+} に よ る$ 収縮は，W-7の濃度に 応じて抑制されることが明らかとなった。特にW-7 $300 \mu \mathrm{M}$ の条件では収縮はほぼ完全に抑制された。 ヒト 膀胱 skinned fiber では，充分な数の標本が得られな かったが， $300 \mu \mathrm{M}$ の W-7による著明な収縮抑制効果 を観察できた. したがって, 膀脱平滑筋においても calmodulin が細胞内 $\mathrm{Ca}^{2+}$ 結合蛋白として筋収縮システ ムに深く関与していると考えられた。

最後に細胞内 Ca-store に関する実験を, 膀胱 skinned fiber を用いて行なった。筋細胞には細胞内におい て $\mathrm{Ca}^{2+を}$ 貯臓，遊離するシステムがあり，骨格筋にお いては収縮制御の重要な因子となっている5)，平滑筋 においては，その主たる貯臓部位と考えられている筋 小胞体の発達が骨格筋に比較し劣り ${ }^{17)}$ 筋収縮における 役割は充分解明されていない，そこで筋小胞体より $\mathrm{Ca}^{2+を}$ 遊離する作用がある caffeineを膀胱 skinned fiber に作用させることにより，膀脱平滑筋に打ける Ca-storeを検討した. $\mathrm{Ca}^{2+}$ 負荷後の caffeineによる skinned fiber の収縮は, $\mathrm{Ca}^{2+} か ゙$ 直接細胞内で store か ら放出されるため収縮速度はきわめて速く，また一過 性であった。この caffeine 投与による skinned fiber の 収縮は, 負荷した $\mathrm{Ca}^{2+}$ 濃度に対し, $10^{-6} \mathrm{M}$ までは dose dependent に増大したが， $10^{-5} \mathrm{M} の \mathrm{Ca}^{2+}$ 負荷する と, caffeine 収縮はむしろ減少する傾向にあった。これ は, ある濃度以上の $\mathrm{Ca}^{2+}$ 負荷すると, $\mathrm{Ca}^{2+}$ 自体が store の $\mathrm{Ca}^{2+}$ を遊離していることを示し，膀胱平滑筋 においても “Ca induced Ca release mechanism"18)19) が存在することが示唆された。

以上, skinned fiber を用いて, 膀胱平滑筋における 細胞内収縮システムについて検討した。細胞内収縮シ ステムは，これまでの結果に示されるように， $\mathrm{Ca}^{2+を}$ 主体として調節されている点が特徵である。したがっ て細胞内で $\mathrm{Ca}^{2+}$ 動態をコントロールできる薬剤は, 従 来臨床で使用されてきた細胞膜レベルで $\mathrm{Ca}^{2+を}$ 制御 するものとは異なった作用機転を持ち, 膀胱収縮に対 しても新たな位置づけがなされる可能性がある。この 意味で skinned fiber 法は, 細胞内収縮システムの研究 のみならず，細胞内で作用する薬剤の開発などに用い ることのできる有力な手法となる，たとえば本研究で
明らかにしたよらに, W-7の著明な抑制効果は, 細胞膜 の受容体が变化してしまった病的膀脱に执いても， calmodulin 阻害剂はその収縮を充分抑制できること を示唆している。現在 calmodulin 阻害剤の他にも， Ca-store からの $\mathrm{Ca}^{2+}$ 遊離を阻害する薬剤20)や，ミオシ ン軽鎖キナーゼ阻害凨等の研究も進められており ${ }^{211}$, 今後この分野に打ける進歩発展は，臨床的にも大きな 利益をもたらすものと期待される.

\section{結 語}

サポニン処理法により膀脱 skinned fiberを作製し， 細胞内収縮機構について検討を加兄, 次の結果を得た。

(1) サポニン処理は, 膀羘平滑筋においても細胞内収 縮システムが良好に保持される有用な実験方法であ る.

(2) 膀胱平滑筋の細胞内収縮システムは, $\mathrm{Ca}^{2+}$ に よってコントロールされており，また $\mathrm{Mg}^{2+} \mathrm{MgATP}$ は細胞内収縮システムの重要な因子である。

(3) $\mathrm{Ca}^{2+}$-calmodulin 系は, 膀胼平滑筋に执いても, 細胞内収縮システムに拈ける主要な経路であることが 示された。

(4) 膀胼平滑筇においても Ca-store は存在し，また $\mathrm{Ca}^{2+}$ 濃度が $10^{-6} \mathrm{M}$ 以上では，“Ca-induced Ca release mechanism"が働くものと思われた。

稿を終えるに当たり，御校閲を賜った恩師白岩康夫教授 に深く感謝の意を表します。

また直接御指導を賜った山口 脩講師に深謝いたしま す.な报, 本論文の要旨は第76回日本泌尿器科学会総会に抒 いて発表した。

\section{文献}

1) Levin, R.M. and Wein, A.J.: Response of the in vitro whole bladder (rabbit) preparation to autonomic agonists. J. Urol., 128, 1087-1090, 1982.

2) Levin, R.M., High, J. and Wein, A.J.: The effect of short-term obstruction on urinary bladder function in the rabbit. J. Urol., 132, 789-791, 1984.

3) Speakman, M.J., Brading, A.F., Gilpin, C.J., Dixon, J.S., Gilpin, S.A. and Gosling, J.A.: Bladder outflow obstruction-A cause of denervation supersensitivity. J. Urol., 138, 1461 $-1466,1987$.

4) Huxley, A.F. and Niedergerke, R.: Structural changes in muscle during contraction. (Interference microscopy living muscle fibers). Nature, 173, 971-973, 1954.

5) Ebashi, S. and Endo, M.: Calcium ion and 
muscle contraction. Progr. Biophys. Mol. Biol., 18, 123-183, 1968.

6) Hartshorne, D.J. and Gorecka, A. : Biochemistry of the Contractile Proteins of Smooth Muscle. Handbook of Physiology, the Cardiovascular System, Chapter 4:91-120, American Physiological Society. Washingtone, D.C. 1980.

7）大槻磐男：細胞のサポニン処理. 生体の科学, 27 , 62-66, 1976.

8) Imai, S. and Takeda, K. : Effect of vasodilators upon the isolated taenia coli of the guinea pig. J. Pharmacol. Exp. Ther., 156, 557-564, 1967.

9) Devine, C.E., Somlyo, A.V. and Somlyo, A.P.: Sarcoplasmic reticulum and excitationcontraction coupling in mammalian smooth muscles. J. Cell Biol., 52, 690-718, 1972.

10) Filo, R.S., Bohr, D.F. and Rüegg, J.C. : Glycerinated skeletal and smooth muscle (Calcium and magnesium dependence). Science, 147, 1581-1583, 1965.

11) Saida, K. and Nonomura, Y.: Characteristics of $\mathrm{Ca}^{2+}$. and $\mathrm{Mg}^{2+}$. induced tension development in chemically skinned smooth muscle fibers. J. Gen. Physiol., 72, 1-14, 1978.

12) Murphy, R.A., Bohr, D.F. and Newman, D.L. : Arterial actomyosin $(\mathrm{Mg}, \mathrm{Ca}$. and ATP Ion dependencies for ATPase activity). Am. J. Physiol., 217, 665-673, 1969.

13) Wachsberger, P.R. and Pepe, F.A. : Purification of urerine myosin and synthetic filament formation. J. Mol. Bio., 88, 385-391, 1974.

14）野々村禎昭：平滑笳の収縮制御. 蛋白質核酸酵素
（臨臨増刊，細胞運動と細胞骨格），28，340-349, 1983.

15) Dabrowska, R., Sherry, J.M.F., Aromatorio, D. K. and Hartshorne, D.J.: Modulator protein as a component of myosin light chain kinase from chiken gizzard. Biochem., 17, 253-258, 1978.

16) Hidaka, H., Asano, M., Iwadare, S., Matsumoto, I., Totsuka, T. and Aoki N.: A novel vasculor relaxing agent, $\mathrm{N}$-(6-Aminohexyl)-5Chloro-1-Naphthalenesul-fonamide which affects vascular smooth muscle actomyosin. J. Pharmacol. Exp. Ther., 207, 8-15, 1978.

17) Porter, R. and Franzini-Armstrong, C.: The sarcoplasmic reticulum. Sci. Am., 212, 73-80, 1965.

18) Endo, M., Tanaka, M. and Ogawa, Y.: Calcium induced release of calcium from the sarcoplasmic reticulum of skinned skeletal muscle fibers. Nature, 228, 34-36, 1970.

19) Saida, K. : Intracellular Ca release in skinned smooth muscle. J. Gen. Physiol., 80, 191-202, 1982.

20) Asano, T. and Hidaka, H.: Vasodilatory action of HA1004[N-(2-Guanidinoethyl)-5Isoquinolinesul-fonamide], a novel calcium antagonist with no effet on cardiac function. J. Pharmacol. Exp. Ther., 231, 141-145, 1984.

21) Saitoh, M., Ishikawa, T., Matsushima, S., Naka, M. and Hidaka, H.: Selective inhibitor of catalytis activity of smooth muscle myosin light chain kinase. J. Biol. Chem., 262, 7796 -7801, 1987.

（1989年11月15日受理） 